\title{
Development of Moringa Olefeira Enriched Muffins
}

\author{
Serere Harusekwi Julien, Nemapare Patience \\ Midlands State University, Department of food Science and Nutrition, Gweru, Zimbabwe
}

Email address:

sererejh@msu.ac.zw (S. H. Julien), patienem@gmail.com (N. Patience)

\section{To cite this article:}

Serere Harusekwi Julien, Nemapare Patience. Development of Moringa Olefeira Enriched Muffins. International Journal of Nutrition and Food Sciences. Vol. 4, No. 2, 2015, pp. 178-183. doi: 10.11648/j.ijnfs.20150402.19

\begin{abstract}
This research was based on the development of Moringa olefeira enriched muffin. Moringa Olefeira has the potential to adequately support dietary needs and increase variety of food products on the market but however its usage in Zimbabwe is limited. Protein, calcium and moisture content were determined in the enriched muffin. The experiments were carried out to estimate nutrient content of protein and calcium and the sensory evaluation (appearance, taste, aroma and texture).The Moringa olefeira muffin contains more protein: $13.9 \mathrm{~g}$ and $15.19 \mathrm{~g}$ for moringa samples B and C respectively while the ordinary sample A has $8.13 \mathrm{~g}$. The moringa muffins also proved to have more calcium than the un-enriched muffin which was $121 \mathrm{mg}$ whilst the enriched samples B and C had $244 \mathrm{mg}$ and $307 \mathrm{mg}$ respectively. The moisture content of the ordinary sample was $24.16 \%$, moringa sample B had $28.1 \%$ and the other moringa sample $\mathrm{C}$ had $28.7 \%$ moisture. The acceptability and preference were compared with that of the ordinary muffin and from the analysis of the responses given by the panelists, they preferred and accepted the moringa enriched muffin. Nutrient analysis indicated that an increase in moringa powder resulted in an increase in protein and calcium content in the moringa enriched muffin. Sensory attributes like aroma, texture, appearance and taste were also acceptable.
\end{abstract}

Keywords: Enriched Muffins, Moringa Olefeira Leaves, Development

\section{Introduction}

Good nutrition is vital throughout one's life cycle. Children's early experiences with food play an important part in shaping their later eating habits, and good eating habits support healthy growth and development.(source). Giving positive messages about food in early years setting will also help stress the importance of a good diet to children's families. Child malnutrition has become the leading cause of death among infants in developing countries, (Robert and McDonald, 2006). Zimbabwe Demographic and Health Surveys (1988, 1994, 1999 and 2005-06) have shown that levels of malnutrition among children under five years had been increasing in the past two decades For example, the prevalence of stunted children under five years increased from $21 \%$ in 1994 to $34 \%$ in 2010 (Zimbabwe Demographic and Health Survey 2005-06; Food and Nutrition Council and the Ministry of Health and Child Welfare, 2010). The deterioration of child nutritional status gave rise to significant increases in nutritional deficiencies related diseases and exacerbating the spread of communicable diseases among children under five years (Food and Nutrition Council and Ministry Of Health and Child Welfare, 2010). The
Government of Zimbabwe (2004) noted that about 34\% of early childhood deaths in Zimbabwe are related to under nutrition.

The diet provided by most families in Zimbabwe is unbalanced and the snacks offered are not nutritious or junk foods like biscuits, jiggies, cakes and sweets while other families in remote parts can go to bed on an empty stomach. This is due to the economic status but while we are in this state it is necessary to find solution to the problem which has led to malnutrition. The rate at which most pupils are eating junk foods instead of a decent meal has drastically increased leading to poor nourishment in infants. The researchers then decided to enrich muffins with Moringa olifera which would inevitably provide a certain percentage of the calcium and protein Recommended Daily Allowances. Moringa olefeira is known popularly as drumstick tree, it is a herbaceous plant grown for its nutritious greens. Moringa is a drought resistant, medium-sized, evergreen tree that prefers warm, frost-free climates to flourish. Its leaves and seeds can be harvested from a wellestablished tree. Sauveur (2001), postulates that Moringa olefeira plant possess unique nutritional qualities that are of benefit to impoverished communities around Zimbabwe that are lacking in many nutritional supplements if 
it is utilised in the diet. According to Lowell (2002), 100 grams of moringa olefeira leaves provide about 9.8 grams of protein. They also have monounsaturated fatty acids like oleic, it is a good source of vitamin A and C as well as the Bcomplex, minerals like calcium, iron, zinc and phosphorus. A lack or deficiency of these nutrients can therefore be detrimental to health, the impaired functioning of other body systems. Fortification involves addition of minerals or other nutrients to increase their content in the food. It serves to assist any individual consuming the food to better meet their nutritional needs. Fortification of the muffins with Moringa olefeira would then allow the consumer to benefit the nutrients therein.

\section{Method}

Drying of Moringa oleifera leaves was the first main stage after they were collected from the trees from the same tree in Binga rural area. The leaves were laid indoors in an open space where they were dried for 3 days of which this time could have been less if the weather was very hot. Drying had to be done indoors and not in the sun, so as to avoid destruction of vital nutrients like vitamin $\mathrm{C}$ and $\mathrm{A}$ which are easily affected by light and heat. Drying was done to eliminate moisture and also to preserve the leaves. After drying the leaves were pounded into a powder using a pestle and mortar.

The development was done through a series of experiments. The actual processing involved the following ingredients and various steps.

\subsection{Calcium Content}

The method used for analysis was the Atomic Absorption Spectroscopy method (AAS). Welz (2010) explain that AAS involves aspirating an aqueous sample into a flame where the analyses areatomized. An isolated atom absorbs light at specific wavelengths which are unique for each element with the amount of absorbed light being directly proportional to the concentration of the analyze. It is due to this property that concentrations of specific components of products can be determined. Calcium absorbs strongly at $239.9 \mathrm{~nm}$ and $422.7 \mathrm{n}$.

\subsection{Protein Content Determination Using Kjedahl Method}

Digestion:

5 grams of the muffin and Moringa olefeira leaves powder sample was placed into a digestion flask and then digested by heating it in the presence of $4 \%$ sulphuric acid (an oxidizing agent which digests the food), anhydrous sodium sulfate (to speed up the reaction by raising the boiling point) and a catalyst, copper, (to speed up the reaction).

Neutralization:

After the digestion had been completed the digestion flask was connected to a receiving flask by a tube. The solution in the digestion flask is then made alkaline by addition of sodium hydroxide, which converts the ammonium sulfate into ammonia gas.
The ammonia gas that was formed was liberated from the solution and moved out of the digestion flask and into the receiving flask which contained an excess of boric acid.

The low $\mathrm{pH}$ of the solution in the receiving flask converts the ammonia gas into the ammonium ion, and simultaneously converts the boric acid to the borate ion:

\subsection{Titration}

The nitrogen content was then estimated by titration of the ammonium borate formed with standard sulphuric acid using a suitable indicator to determine the end-point of the reaction.

The concentration of hydrogen ions (in moles) required to reach the end-point was equivalent to the concentration of nitrogen that was in the original food.

A blank sample was run at the same time as the material being analyzed to take into account any residual nitrogen which may be in the reagents used to carry out the analysis.

After nitrogen content was determined, it was converted to a protein content using the appropriate conversion factor: $\%$ Protein $=\%$ Nitrogen $\mathrm{X}$ Factor specific for sample type

Of which the factor for wheat products is 6.25 .

\subsection{Moisture}

Each sample was carefully weighed to $1.000 \pm 0.001 \mathrm{~g}$ and placed in a pre weighed foil envelope, pre-marked with the sample code and sample weight was recorded. The envelopes were placed in an oven at 213 degrees Celsius for 3 hours after which they were removed from the oven and immediately placed in a desecrator for 10 minutes until the weight was constant, and cooled to room temperature. Subsequently, the samples were removed, the final masses recorded and the percent moisture of each sample calculated.

\subsection{Sensory Evaluations}

Stone and Sidle (2007) explains that sensory evaluation is a science that measures, analyses and interprets the responses of people to products as perceived by the senses. Acceptance can be measured using various methods. Among these is the 9-Point hedonic scale. Stone and Sidle (2007) describe the 9Point hedonic scale as a more useful tool because it gives a measure for liking each product, the magnitude of the difference in liking among the products and enables use of parametric statistics to identify significant product differences.

\section{Results and Discussions}

\subsection{Nutrient Analysis Results}

Table 3.1. Nutrient composition of Moringa Olefeira leaves powder.

\begin{tabular}{ll}
\hline Nutrient & Amount/100g \\
\hline Protein & $9.10 \mathrm{~g}$ \\
Calcium & $460 \mathrm{mg}$ \\
\hline
\end{tabular}

According to Table 1, the protein content for the Moringa 
Olefeira is slightly lower than the amounts stated in the literature researched which is $9.8 \mathrm{~g}$ per $100 \mathrm{~g}$ of the leaves powder. The protein content was high as postulated in literature. Table 4.1above shows that Moringa Olefeira has high amounts of calcium which was about 460mg per 100gramsafter analysis.

\subsection{Nutrient Composition of Muffins Results}

Table 3.2. Nutrient composition of the muffins.

\begin{tabular}{|c|c|c|c|}
\hline Nutrient & $\begin{array}{l}\text { Moringa- } \\
\text { free Muffin }\end{array}$ & MoringaenrichedMuffin & $\begin{array}{l}\text { Moringa } \\
\text { enriched } \\
\text { Muffin }\end{array}$ \\
\hline $\begin{array}{l}\text { Moringa } \\
\text { Quantity }\end{array}$ & Sample A & $\begin{array}{l}\text { Sample B } \\
\text { (100grams) }\end{array}$ & $\begin{array}{l}\text { Sample C } \\
\text { (150grams) }\end{array}$ \\
\hline Protein & $8.13 \mathrm{~g}$ & $13.9 \mathrm{~g}$ & $15.19 \mathrm{~g}$ \\
\hline Calcium & $121 \mathrm{mg}$ & $244 \mathrm{mg}$ & $307 \mathrm{mg}$ \\
\hline
\end{tabular}

Table 3.2showed that the protein content of the Moringa Olefeira enrichedmuffin samples B and Cwere high and the control sample A had the leastprotein and calcium. The protein content of the Moringa olefeira muffinsample B had $25 \%$ more protein of the ordinary muffin. Sample $C$ had about $90 \%$ more than that of the moringa free muffin sample A and about 50\% more than Moringa muffin sample B which had about $13,9 \mathrm{~g}$ of protein. The calcium content of the muffins was highest in the Moringa enriched muffin sample $\mathrm{C}$ which was $307 \mathrm{mgand}$ lowest in the ordinary muffin which had not been enriched which was $121 \mathrm{mg}$.

\subsection{Moisture Content Analysis}

Table 3.3. Results showing wet sample and dried sample

\begin{tabular}{lll}
\hline Sample name & Wet sample weight/g & Dried sample weight/g \\
\hline $\begin{array}{l}\text { Ordinary muffin } \\
\text { sample A }\end{array}$ & 5,0147 & 1,2313 \\
$\begin{array}{l}\text { Moringa muffin } \\
\text { sample B }\end{array}$ & 5,0016 & 1,405 \\
$\begin{array}{l}\text { Moringa muffins } \\
\text { sample C }\end{array}$ & 4,9829 & 1,4291 \\
\hline
\end{tabular}

The results in table 3.3 showed variations in the weights ofthe wet samples of the ordinary muffin, moringa muffin sample A and moringa muffin sample Cwere 5,0147;5,0016 and 4,9829 respectively. The dry mass was also recorded after drying and it was 1,2313;1,405 and 1,4291 respectively. The moisture content was then calculated as a percentage and the results are shown on the table below.

\subsection{Results Showing the Moisture Content of Muffins}

Table 3.4. Percentage moisture contents of the muffins.

\begin{tabular}{ll}
\hline Sample & \%Moisture \\
\hline A & 24,16 \\
B & 28,1 \\
C & 28,7 \\
\hline
\end{tabular}

There were variations in the moisture content of the different samples .Sample Awhich was unfortifiedhad theleast $24,16 \%$ of moisture content, sample B had $28,1 \%$ moisture while sample $\mathrm{C}$ had $28,7 \%$ moisture content as shown in table 3.4 above.

\subsection{Results for Sensory Evaluation}

The sensory evaluation was done for both the Moringa enriched muffin and the data collected was analysed collectively to ensure that accurate results are obtained.

Table 3.5. Results showing moringa enriched muffin.

\begin{tabular}{lllll}
\hline $\begin{array}{l}\text { Moringa } \\
\text { enrichedMuffin }\end{array}$ & Taste & Aroma & Appearance & Texture \\
\hline Like extremely & 9 & 7 & 10 & 14 \\
Like very much & 6 & 7 & 6 & 5 \\
Like moderately & 2 & 6 & 6 & 2 \\
Like slightly & 2 & 5 & 2 & 3 \\
Neither like nor & 5 & - & 2 & 3 \\
dislike & & - & & \\
Dislike slightly & - & - & - & - \\
Dislike moderately & - & - & - & - \\
Dislike very much & - & - & - & - \\
Dislike extremely & - & - & - & - \\
\hline
\end{tabular}

Theresults intable 3.5 aboveshows that 9 people of the totalrespondents liked extremely the taste of themoringa muffin, only 6 liked very much, 2 liked moderately while 2liked slightly however 5 respondents were indifferent on the taste of the enriched muffin. The aroma of the muffin was less preferred as 7 respondents liked extremely, 7 others liked the aroma very much and 6 of the participants liked slightly. The highest number of individuals liked the appearance of the muffin, the other 5 liked very much, while the other 6 liked very much and the other 6 liked moderately and the other 5 liked slightly.

The texture of the moringa muffin was liked extremely by about 14 people and 5 liked very much while 2 liked moderately and the other 3 liked the texture of the moringa muffin slightly and 3 of the respondents neither liked nor disliked the muffin as shown in table 3.5 above. The respondents liked the muffin and none of them disliked the moringa muffin and on the other hand about 10 were indifferent thus they neither liked nor disliked the muffin.

Table 3.6. Results for Moringa free Muffin.

\begin{tabular}{lllll}
\hline Moringa freeMuffin & Taste & Aroma & Appearance & Texture \\
\hline Like extremely & 8 & 9 & 6 & 9 \\
Likevery much & 4 & 5 & 6 & 5 \\
Likemoderately & 10 & 5 & 9 & 3 \\
Likeslightly & 3 & 2 & 2 & 4 \\
Neither like nor dislike & 2 & 2 & - & - \\
Dislikeslightly & 1 & 3 & 1 & 2 \\
Dislikemoderately & - & 1 & - & - \\
Dislikevery much & - & - & - & - \\
Dislike extremely & - & - & - & - \\
\hline
\end{tabular}

The table 3.6showed results on sensory evaluation, where 8 of the 30 respondents liked the taste of the ordinary muffin 
extremely, 4 liked very much and 10 of the respondents liked moderately, about 3 of the total population liked the taste of the moringa free muffin slightly and 2 people neither liked nor disliked the texture of the muffin which was not enriched and only 1 disliked slightly. The aroma of the moringa free muffin was liked extremely by 9 respondents, 5 people liked very much while 5 others liked moderately and 2 liked slightly, 2 of the 30 respondents neither liked nor disliked the aroma of the moringa free muffin and jus 1 person disliked the aroma of the ordinary muffin.

The appearance of themoringa free muffin was extremely liked by 6 individuals and 6 others liked very much, 9 of them liked moderately while 2 only liked slightly the appearance of the ordinarymuffinand none of the respondents were indifferent about the appearance but however 1 person disliked the moringa free muffin slightly. The texture of theordinary muffin was liked extremely by 9 people, 5 of the 30 respondents liked very much and 3 people liked moderately while 4 people liked slightly and none of the respondents neither liked nor disliked the appearance of the moringa free muffin and only 1 disliked the appearance of the muffin. There were no respondents in the populationwho disliked any of the attributes very much or disliked extremely.

\subsection{Results Showing Preferences for Moringa Olefeira Muffin (Sample B)}

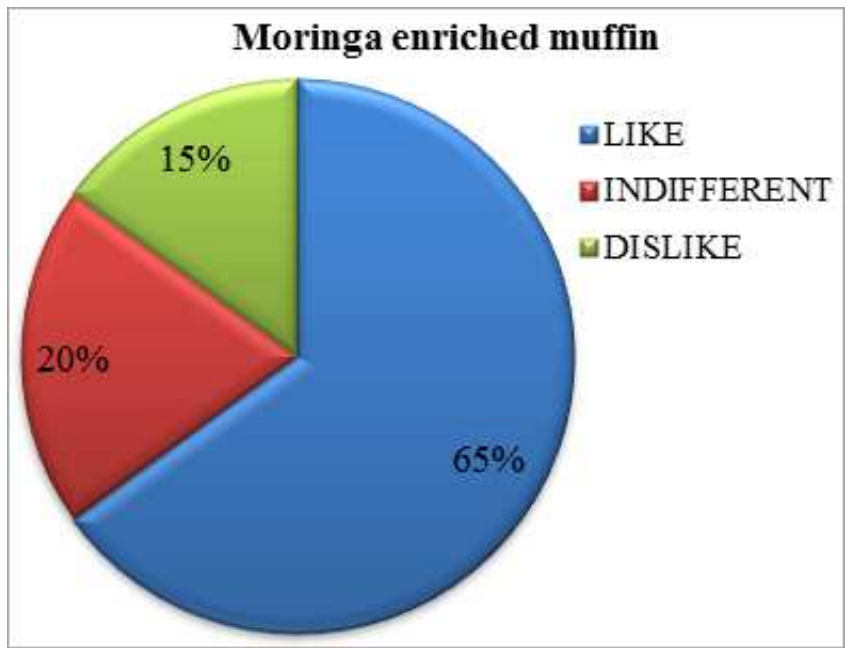

Fig. 1. Results showing Moringa muffin.

The above data in fig. 1 shows the results of the different preferences andattitudes towards the moringa muffin whereby $65 \%$ of the total population liked the Moringa olefeira muffin, only $20 \%$ of the respondents were indifferent towards the muffin but on the other hand about 15 individuals disliked the moringa enriched muffin.

\subsection{Results Showing Preferences for Moringa Free Muffin (Sample A)}

Fig. 2 above shows the different preferences for the moringa free muffin whereby half or $50 \%$ of the population liked the moringa free muffin which was not enriched and $40 \%$ of the respondentsneither liked nor disliked the moringa free muffin while $10 \%$ disliked the moringa free muffin.

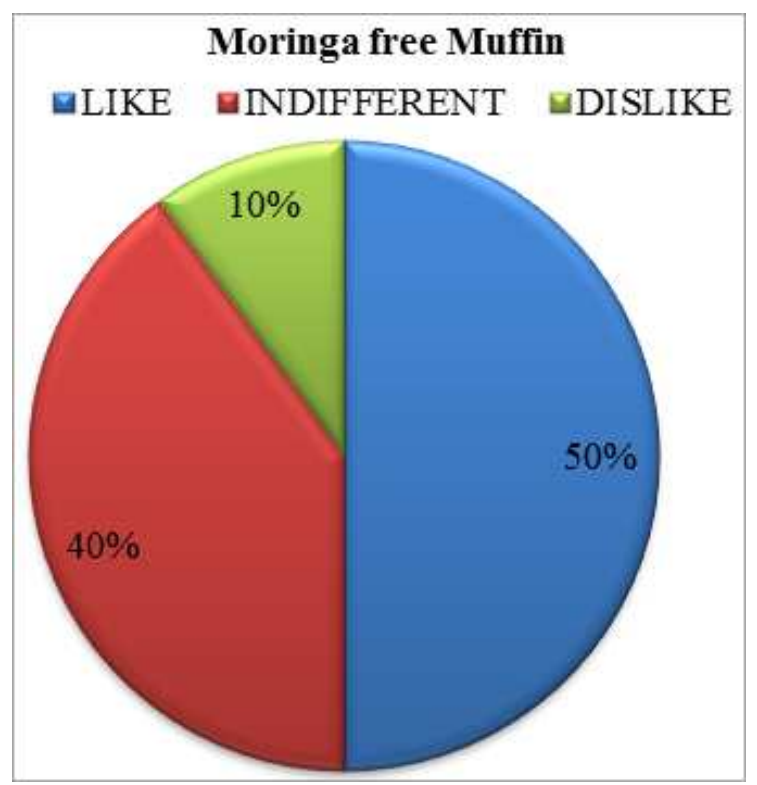

Fig. 2.Results showing preferences for Moringa free muffin.

\subsection{Taste}

Taste is defined as the sensation perceived via taste buds due to the presence of certain soluble substances. Fig 3 below show that $88 \%$ of the respondents liked the taste of the enriched muffin while $62 \%$ of the population liked the taste of the ordinary muffin again. None were indifferent about the taste of both of the muffin and $22 \%$ disliked the taste of the enriched muffin with $18 \%$ disliking the ordinary muffin.

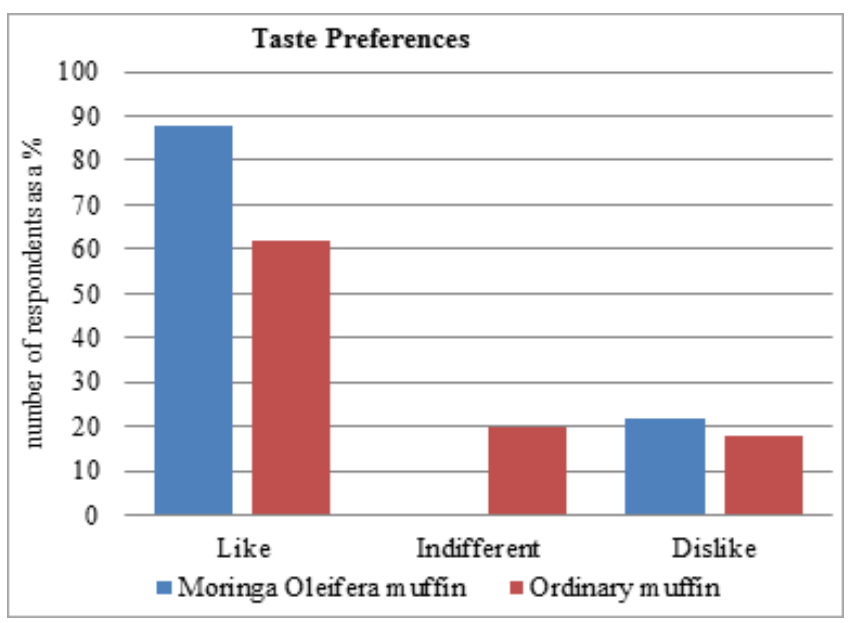

Fig. 3. Results showing Taste Preferences.

\subsection{Aroma}

Aroma is a sensory impression of a food that is determined by the chemical sense of smell, some reactions during bakingare capable of producing a wide range offlavours or aroma .In this case the aroma of the enriched muffin was liked by about $85 \%$ of the respondentsand 5 individuals were indifferentwhile none disliked the aroma of the Moringa olefeiraenriched muffin as shown in fig. 4 below .On the 
other handonly $60 \%$ of therespondents liked the aroma of the ordinary muffin ,37\% were indifferent and about $3 \%$ of therespondents disliked the ordinary muffin.

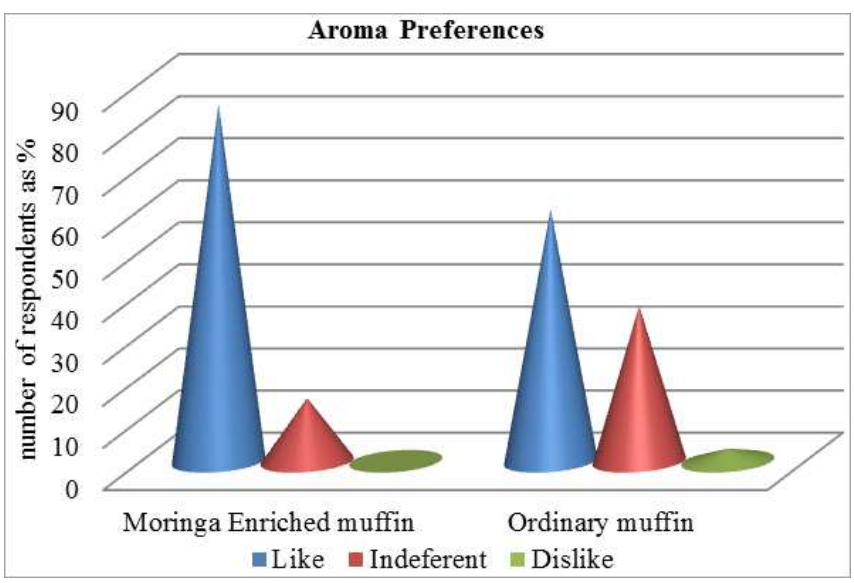

Fig. 4. Results showing aroma preferences.

\subsection{Appearance}

The scores for the appearance were fair, about $85 \%$ of the population liked the appearance and $10 \%$ were in different while $3 \%$ disliked the appearance and also added on the comments that there is need to improve the appearance, of the Moringa olefeira enriched muffin. There were various preferences also for the ordinary muffin whereby $90 \%$ of the population liked the appearance of the ordinary muffin, no one was indifferent and 10 disliked them. Respondents commented that there was a need to improve the colour of the muffin while others suggested that they felt the colour of the product was appropriate and a representative of a herbal food. Also on the other hand some respondents commented that the enriched muffin be flavoured with fruits like strawberries for them to look appealing to the people.

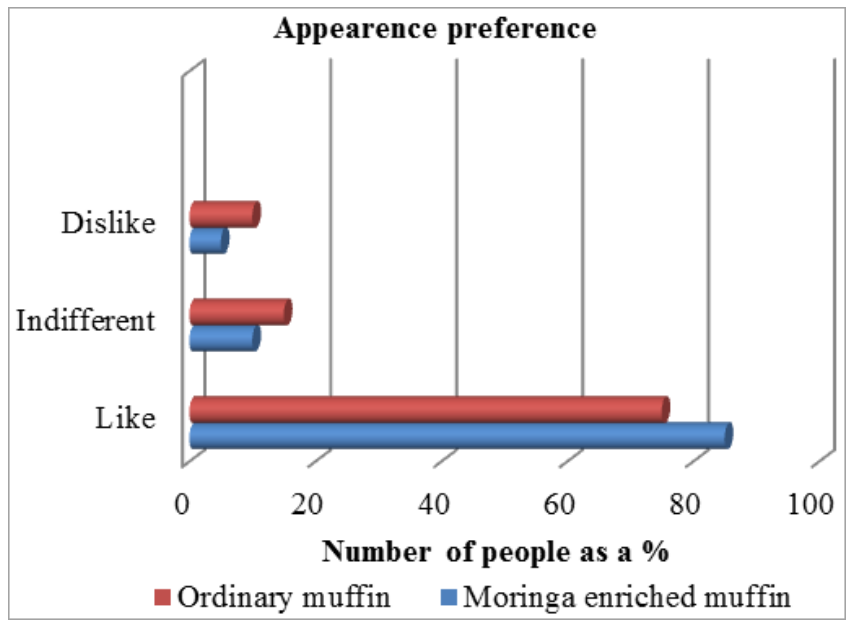

Fig. 5. Appearances Preferences.

\subsection{Texture}

Texturewhich can also be termed mouthfeel is a complex sensory attribute encompassing feeling and trigeminal impulses of texture, heat, coolness, sponginess, lubricity or hardness, which at times is also referred to as texture is a complex sensory attribute encompassing feeling and trigeminal impulses of texture, heat, coolness, sponginess, lubricity, sliminess or chalkiness. The majority of the participants liked the texture of both samples. The moringa enriched had the highest rating of preference with $95 \%$ of the population liked the muffin while $80 \%$ liked the ordinary muffin, less than $20 \%$ of the population were indifferent while $11 \%$ of the respondents disliked the texture of the ordinary muffin. Some respondents commented that the texture needed to be improved as the coarse particles of the ground leaves may result in an unpleasant texture.

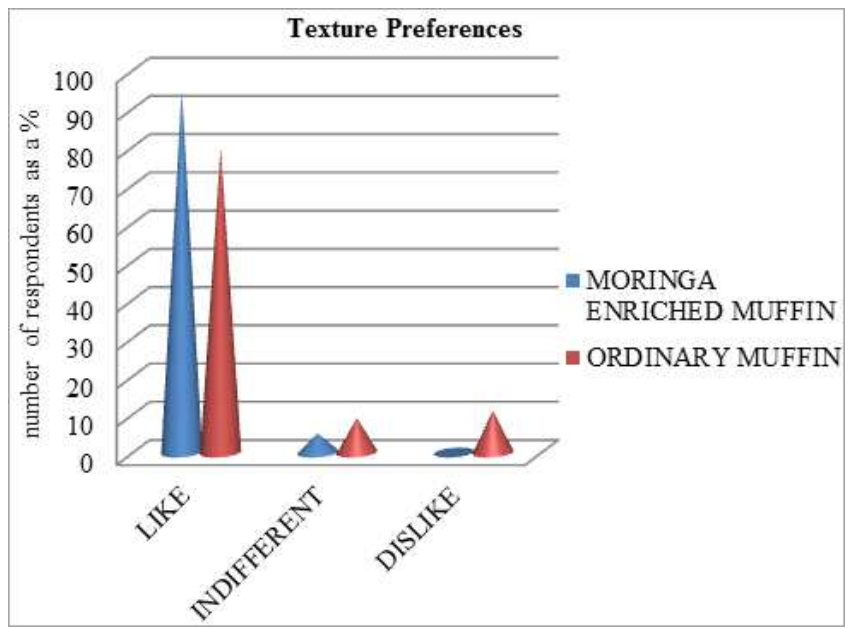

Fig. 6. Results showing Texture preferences.

\subsection{Overall Acceptance of the Muffins}

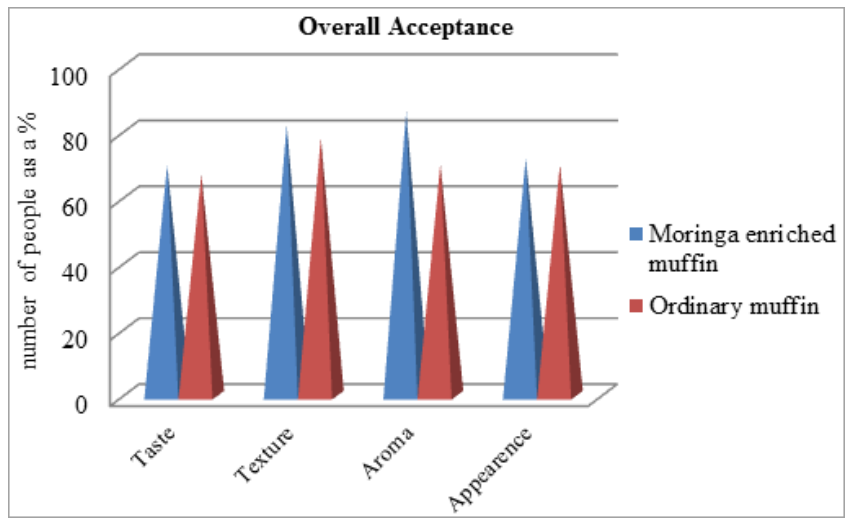

Fig. 7. Results showing overall acceptance.

Fig 7 shows results of the differences in acceptance of the Moringa olefeira muffin and ordinary muffin. The Moringa Olefeira muffin was well accepted by members of the sensory panel. About $72 \%$ of the participants accepted the appearance of the moringa muffin. Attributes such as taste however had less had fewer acceptances with $70 \%$ of the population, but through they were higher than acceptance for the ordinary muffin. The overall acceptance of the texture was $72 \%$ while texture for the ordinary muffin was $78 \%$. The texture ofmoringa muffin was acceptance by $82 \%$ of the participants while $78 \%$ of participants accepted the texture. 


\section{Conclusion}

Moringa olefeirais a plant source which is rich ina number of nutrientlike proteins, essential fats like omega 3 (alpha linoleic)and omega 6 (linoleic),mineral elements like calcium, iron and many others as well asvitamins both water soluble vitamin C,B-complexand fat soluble vitamin $\mathrm{A}, \mathrm{K}$ and $\mathrm{E}$ and fibre (Jahn, 1998). A 100grams of dried leaves of moringa tree contain about $9.8 \mathrm{~g}$ of protein and of calcium and the amounts obtained in this research were slightly less than those values as protein was 9.1grams and calcium was $460 \mathrm{mg}$ which is within the range and this proved that the moringa leaves containhigh protein and calcium as claimed in literature (Fuglie, 2002).

Suggestions can safely be made to recommend the moringa as a good source of protein and calcium.

\section{References}

[1] Chardwick, R. Herison, S. Moseley, B, Koeneng. Lia Koponlos, M, Midden, C, Paula (2008),Functional Foods. USA. Springer.

[2] Daayf. F. and Lattanzio, V. (2008),Recent Research in Polyphenol Research, Vol 1, USA Wiley Blackwell Fahey Jed,( 2005) :Moringa Olefeira :A Review of theMedical Evidence for itsNutritional ,Therapeutic, and Prophylactic; USA Properties: 1:5.

[3] Fowler, L. (2011), 7 Miracle Leaves, Awana: Book locker.

[4] Gibson, G. R. and Williams, C. M. (2007), Functional Foods: Concept to Product. New York: Wood head Publishing.

[5] Hamrick, I. and Counts, S. H., (2008), Vitamin and mineral supplements, Wellness Prevent, 35: 729-747.

[6] HDRA, The organic organisation, Moringa Olefeira, A multipurpose tree.

[7] Hoshmand R.A. (1994), Experimental Research design and Analysis: A practical approach forAgriculture and natural sciences, C.R.P. Press, USA.

[8] Holst, S. (2011). Moringa, 2nd Ed. California: Santorini Publishing.

[9] Jahn, S. A. A. (1998), Using Moringa Seeds as Coagulants in Developing Countries, Journal Awwa (Management Operations), 10: 43-50.

[10] Johnson.C.B.(2005), Clinical Perspectives on the Health Effects of Moringa Olefeira: Apromising Adujunalt for balanced nutrition of better health: KOS Health Publications.

[11] Lathan, M. C. (1997),Human Nutrition in the Developing World, Agriculture Organization Food and Nutrition.

[12] Lawless, H. T and Hayman, H. (1999),Sensory Evaluation of Food: Principles and Practices (2nd Ed), USA: Springer.
[13] Makkar, H. P. S. and Becker, K. (1997),Nutrients and ant quality factors in different morphological parts of the Moringa Oleifera tree, Journal of Agricultural Science, Cambridge 128: 311-322

[14] Margel, D. L. (2002), The Nutrient-Dense Eating Plan: A Lifetime Eating Guide to Exceptional Foods. USA: Grothic Publishing. .

[15] Maroyi, A., (2006), Preliminary Checklist of Introduced and Naturalized Plants in Zimbabwe, Kirkia, 18:2.

[16] Moyo, B., Masika, P. J., Hugo, A., Muchenje, V. (2011),Nutritional characterization of Moringa (Moringa Oleifera Lam.) leaves. African Journal of Biotechnology. 10(60): 12925-12933.

[17] Oliver-Bever, B. (1996),Medicinal Plants in Tropical West Africa, Cambridge: Cambridge University Press.

[18] Olson, M. E. (2001),Introduction to the Moringa family. p11-28. InFuglie L. L. (ed.).

[19] The Miracle Tree - Moringa Oleifera: Natural Nutrition for the Tropics. Senegal: Church World Service.

[20] Oluduro, A. (2010), The Use Of Moringa Oleifera Seed for Water Purification. USA: LAP LambartAcad

[21] Ottaway, P. B. (2008), Food Fortification and Supplementation: Technological, Safety and Regulatory Aspects. New York: Woodhead Publishing Ltd.

[22] Pamplona-Roger, H. (2011),Encyclopedia of Foods and their Healing power: A Guide to Food Science and Diet Therapy. China: Editorial Safeliz.

[23] Phytotherapy (2006), Moringa Olefeira: A food plant with multiple medicinal uses, Wiley interscience Pakistain Research Dol.

[24] Price. M. L (2007), Moringa tree. ECHO Technical Note USA.

[25] Saint Sauveur de Armelle (2001) Moringa Exploitation.

[26] Shrilakshmi, B. (2010). Food Science (5th Ed), India: New Age International Publishers.

[27] USDA National Nutrient Database, Moringa Olefeira: Percentage Daily Recommended Allowance. USA

[28] Verdcourt, B. (2005), A synopsis of the Moringaceae. Kew Bul. 40 (1): $1-15$.

[29] Welz, B. (2010), Atomic Absorption Spectroscopy. Michigan: Verlay.

[30] World Health Organisation Readers Forum (1999).

[31] Yang, R., Tsou, S. C. S., Lee, T. Chang, L., Kno, G. and Lai, P. (2000) Moringa, a novel 1 plant rich in antioxidants, Bioavailable iron and nutrients ACS symposium series, 925: 224-239Zimbabwe Health and Demographic Survey (2006). 